\title{
Contamination of titanium dental implants: a narrative review
}

\author{
Jagjit Singh Dhaliwal ${ }^{1}$ (i) - Sheba Rani Nakka David ${ }^{1}$ - Nurul Ramizah Zulhilmi ${ }^{1}$ - Sachinjeet Kaur Sodhi Dhaliwal ${ }^{1}$. \\ Joe Knights ${ }^{1} \cdot$ Rubens Ferreira de Albuquerque Junior $^{2}$
}

Received: 13 November 2019 / Accepted: 22 April 2020 / Published online: 4 May 2020

(C) The Author(s) 2020 OPEN

\begin{abstract}
Contamination of titanium dental implants may lead to implant failure. There are two major types of contaminants: the inorganic and organic contaminants. The inorganic contaminants mostly consist of elements such as calcium, phosphorus, chlorine, sulphur, sodium, silicon, fluorine and some organic carbons. Whereas organic contaminants consist of hydrocarbon, carboxylates, salts of organic acids, nitrogen from ammonium and bacterial cells/byproducts. Contaminants can alter the surface energy, chemical purity, thickness and composition of the oxide layer, however, we lack clinical evidence that contaminations have any effect at all. However, surface cleanliness seems to be essential for implant osseointegration. These contaminants may cause dental implants to fail in its function to restore missing teeth and also cause a financial burden to the patient and the health care services to invest in decontamination methods. Therefore, it is important to discuss the aetiology of dental implant failures. In this narrative review, we discuss two major types of contaminants: the inorganic and organic contaminants including bacterial contaminants. This review also aims to discuss the potential effect of contamination on Ti dental implants.
\end{abstract}

Keywords Dental implant $\cdot$ Contamination $\cdot$ Prognosis $\cdot$ Titanium

\section{Introduction}

Dental implants can get contaminated due to the ecological system in the oral cavity with abundant microorganisms [1]. Common elemental contamination from organic carbon and traces of elements including oxygen $(\mathrm{O})$, nitrogen $(\mathrm{N})$, calcium $(\mathrm{Ca})$ and phosphorus $(\mathrm{P})$ found on dental implant surfaces are potentially linked to failure in re-osseointegration when parts of an implant had lost its osseointegration [2]. It has been shown re-osseointegration occurs when there is a formation of a direct structural and functional union between an implant and bone, it has been shown that properly cleaned implants indeed may re-osseointegrate [3]. Hence several factors such as surface topography, chemical purity, thickness and composition of the oxide layer, surface cleanliness, and the existence of metallic and non-metallic compounds on the surface seems to influence the success of implant osseointegration [4].

Currently, a growing amount of evidence $[5,6]$ suggests that the implant surface topography and chemistry has great influence on the osseointegration process by affecting protein signalling and cell migration or differentiation. Bone-implant contact area, mechanical interlocking and stress distribution are recognisably better in surfaces with a certain degree of roughness in comparison to smooth ones, favouring osteoblast-like cell colonisation [7]. However, it has also been shown that roughened surfaces enhance the accumulation of contaminants [8]. Nevertheless, the mechanisms by which inorganic and organic contaminants interact with the implant surfaces remain undefined. Although many methods of implant

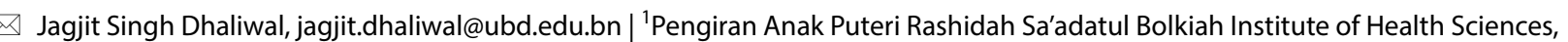
Universiti Brunei Darussalam, Jalan Tungku Link, Gadong, Brunei Darussalam. ${ }^{2}$ Departamento de Materiais Dentários E Prótese, Faculdade de Odontologia de Ribeirão Preto, Universidade de São Paulo, São Paulo, Brazil. 
decontamination have been attempted, none of them have succeeded in producing predictable results. Implant surface decontamination remains challenging and thus the development of new, effective methods is necessary $[9,10]$.

Topographical modification is frequently adopted in titanium-based implants to produce the desired surface properties by using different surface treatments surface treatments such as sandblasting, chemical etching, anodization, laser treatment, and surface coatings [11]. Although these surface treatments can change the properties of the implant surfaces and on rare occasions, may also lead to undesired properties and hence, contamination of the implant surfaces.

Human body fluids contain trace elements such as chlorine and fluoride ions whereas our bone comprise of collagen, hydroxyapatite $\left(\mathrm{Ca}_{10}\left(\mathrm{PO}_{4}\right)_{6}(\mathrm{OH})_{2}\right)$, and some anionic and cationic substituents such as carbonates $\left(\mathrm{H}_{2} \mathrm{CO}_{3}\right)$, sodium ( $\mathrm{Na})$, magnesium $(\mathrm{Mg})$, zinc $(\mathrm{Zn})$, fluorine $(\mathrm{F})$, chlorine $(\mathrm{Cl})$, potassium $(\mathrm{K})$ and silicon $(\mathrm{Si})[12]$. Thus, when the foreign materials are implanted in the human body, they encounter a hostile corrosive environment comprising of various media such as blood, water, $\mathrm{Na}, \mathrm{Cl}$, plasma, amino acids, and mucin in saliva [13].

Inorganic metal oxide such as titanium oxide $\left(\mathrm{TiO}_{2}\right)$ and its alloys are commonly used in dental implants due to its favourable biocompatibility and mechanical properties. The ability of the oxide layer of titanium (Ti) to withstand the corrosion in saline and acidic environment make it an excellent implant material increasing the chance of reosseointegration [14]. However, after long term interaction with living tissue, the $\mathrm{TiO}_{2}$ will release small amounts of corrosion products and lead to dental implant contamination [14]. Corrosion due to bodily fluids can cause changes in material structure and release of unwanted inflammatory by-products, and compromise implant's mechanical stability [15].

Dental implants may also be contaminated when they are marketed, i.e. prior to any contamination from the oral cavity. Therefore, there is a possibility that contaminations may also depend on other matters than biological in situ effects. Therefore, sterile packaged medical devices must be periodically reviewed and documented by the manufactures that the implants are free of surface impurities [16].

Another cause of dental implant contamination is galvanic corrosion. This is an electrochemical process that occurs when electrons can flow freely between two different materials with sufficiently different electrical potentials [17].

The key circumstances that could influence the initial healing phase of the implant site and the survival rate of dental implants are the surgical factors, the time of implant surgery, site of implant placement, type of implant osteotomy, implant design and implant stability [18]. These factors heavily influence the probability of exposure to contaminants. These contaminants may cause dental implants to fail in their function to restore missing teeth. Also, there is and also cause a financial burden to the patient and the health care services to invest in decontamination methods. Therefore, it is important to discuss the aetiology of dental implant failures. In this review, we discuss two major types of contaminants: the inorganic and organic contaminants including bacterial contaminants. This review also aims to discuss the potential effect of these contaminants on Ti dental implants.

\section{Inorganic contaminants}

\subsection{Reactive oxygen and nitrogen species (RONS)}

Reactive oxygen and nitrogen species (RONS) are free radicals and reactive molecules derived from molecular oxygen and nitrogen species, both as intercellular as well as intracellular messengers. As can be seen in Table 1, RONS can be found in lasers (i.e. LLLT-low-level laser therapy), photosensitizers, bleaching agents, cold plasma, and resin cement as a by-product from dental applications [19]. At low or moderate concentration of RONS, it has beneficial effects which results in the angiogenesis (formation of new blood vessels), proliferation and re-epithelialisation of cells in the gingival and other tissues of the body, and vascular endothelial growth factor (VEGF) induced cell migration [18]. However, at very high levels of reactive oxygen species (ROS), adverse effects may rise causing peri-implant inflammation, carcinogenesis \& mutagenesis, mitochondrial dysfunction and cell death $[19,20]$.

\subsection{Calcium (Ca)}

A large amount of the Ca contamination was found in the sodium hydroxide $(\mathrm{NaOH})$ reagent [21]. Kizuki et al. [21] verified that treatment of $\mathrm{Ti}$ with $\mathrm{NaOH}$ reagent and heat treatments induced apatite formation with bone-bonding ability with Ti metal. Unfortunately, with increasing volume of $\mathrm{NaOH}$ reagent, the apatite formation was decreased due to $\mathrm{Ca}$ contamination found in the $\mathrm{NaOH}$ reagent. The $\mathrm{Ca}$ inhibited apatite formation on the Ti metal in SBF (Synthetic/Simulated Body Fluid) by suppressing Na ion release from the sodium titanate into the surrounding fluid. Even a Ca contamination level of $0.0005 \%$ of the $\mathrm{NaOH}$ reagent was sufficient to inhibit the apatite formation [21]. Exposure of Ti to simulated physiological solutions (i.e. Ringer's solution and saline, which contains calcium and phosphate ions) leads to adsorption of calcium phosphate 


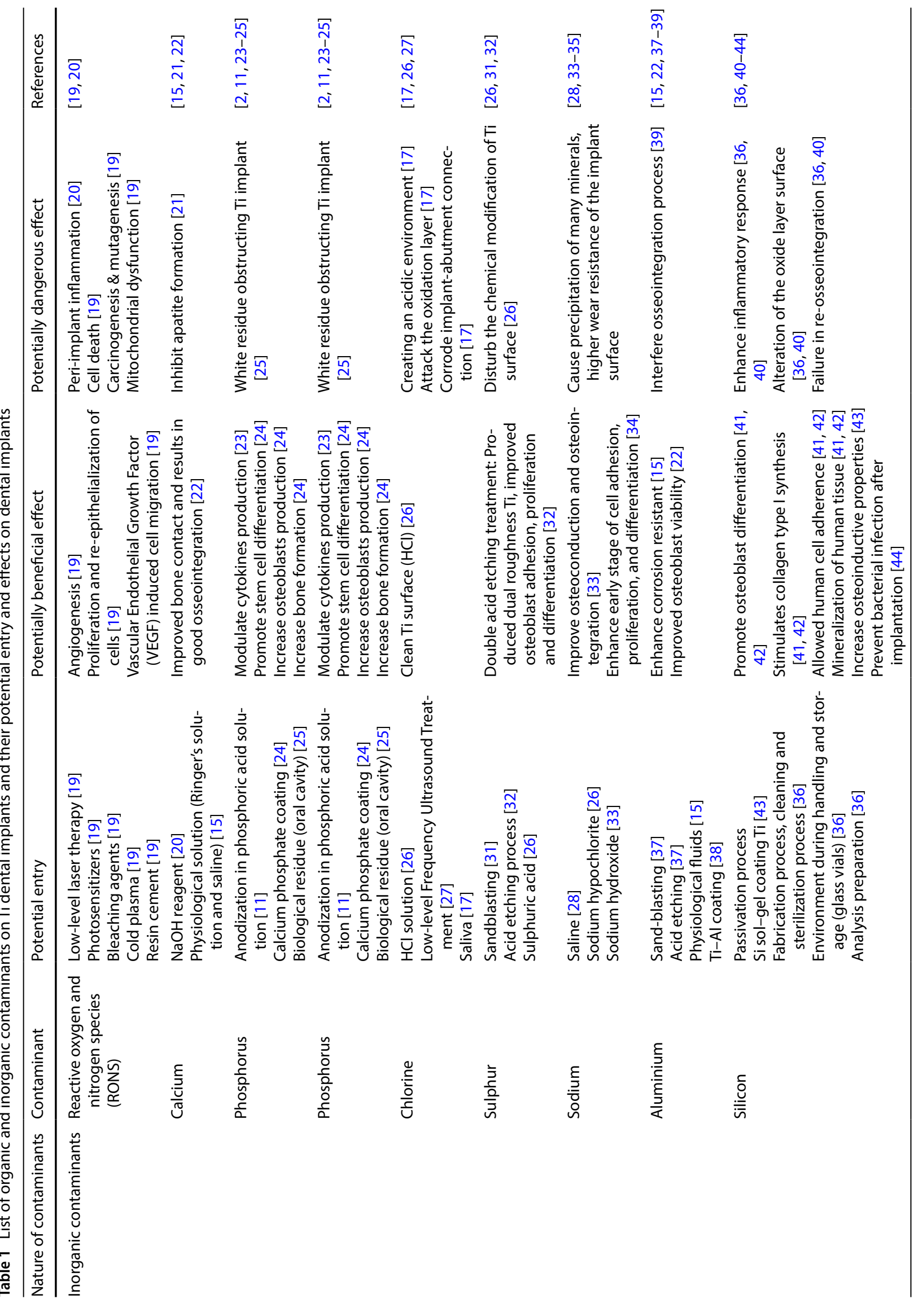




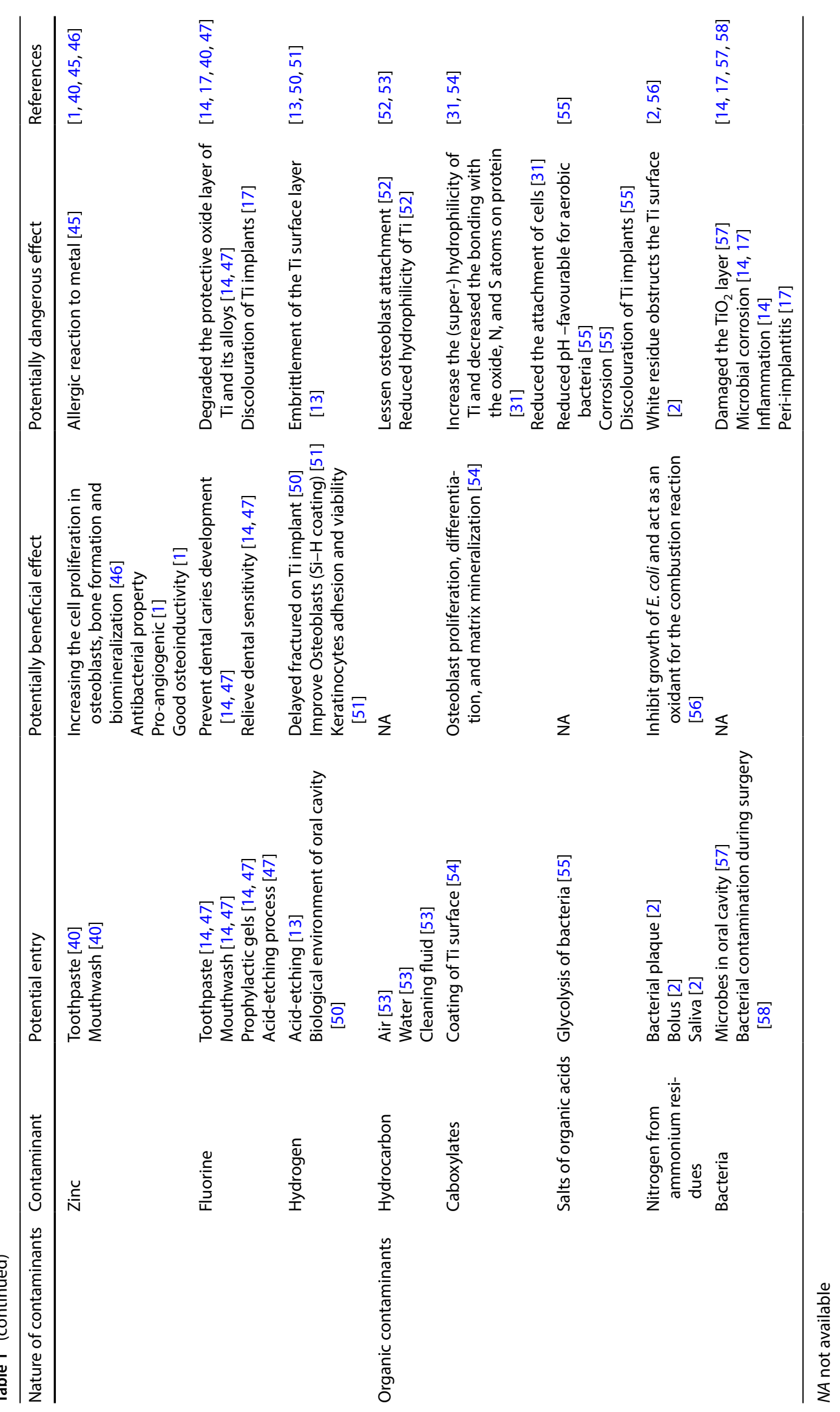


on the surface of the oxide layer, spontaneously [15]. Positively charged $\mathrm{Ca}$ ions attached to negatively charged $\left(\mathrm{PO}_{4}\right)^{3-}$ and $\left(\mathrm{CO}_{3}\right)^{2-}$ acting as nucleation sites for apatite and improving bone to implant contact, thus resulting in good osseointegration [22].

\subsection{Phosphorus (P)}

Chemical composition of the surface of the Ti dental implants plays an important role creating a surface where the bone cells can attach well thus allowing osseointegration to occur. A study had been conducted to examine the surface phosphorus contents of anodized medical-grade Ti samples [11]. The Ti samples were anodised in phosphoric acid solution at different voltages $(10 \mathrm{~V}, 20 \mathrm{~V}, 30 \mathrm{~V}$ or $40 \mathrm{~V})$ and created $\mathrm{TiO}_{2}$ layers on the surfaces. Anodisation in phosphoric acid solution increases the phosphor content of the surface may promote osseointegration and lead to secondary stability for the dental implants [11].

Furthermore, dental implant surfaces treated with $37 \%$ phosphoric acid modulates cytokine production by blood mononuclear cells, establishing a balance between proteins with anti and pro-inflammatory activity, thus promoting the success of dental implants [23]. A Ti surface coating based on calcium phosphate showed high hydrophilicity and high osseointegration, promoting stem cell differentiation, increasing osteoblast production and bone formation, thus resulting in increasing bone formation in a shorter time [24].

One study characterized the surface of Ti healing abutments before and after clinical placement to investigate the effects of the oral environment on device surfaces [25]. The researchers found a thick white residue containing $C$, $\mathrm{N}, \mathrm{O}, \mathrm{Ca}$ and $\mathrm{P}$ completely obstructing the Ti surface. They suggested that the presence of $P$ contaminant came from biological residue of the oral cavity.

\subsection{Chlorine (CI)}

Hydrochloric acid $(\mathrm{HCl})$ was used to clean the Ti surface. However, a minimal amount of $\mathrm{Cl}$ was detected on the implant surfaces. Fortunately, small amount of $\mathrm{Cl}$ did not weaken the Ti surfaces as the $\mathrm{Cl}$ formed $\mathrm{Ti}-\mathrm{Cl}$ complex and soluble in water [26]. Another potential contamination by $\mathrm{Cl}$ was from sonicated solution of low-frequency ultrasound (used to treat chronically infected wounds). The sonication solution from the ultrasound treatment was able to alter the Ti surface chemistry, depositing $\mathrm{Cl}$ as well as $\mathrm{Ca}$, aluminium (Al), $\mathrm{Si}, \mathrm{Na}$ and $\mathrm{K}$ on the implant surface [27].

Saliva contains $\mathrm{K}, \mathrm{Na}, \mathrm{N}$, chloride, bio-actonate products and proteins. However, during crevice corrosion, the concentration of chloride ions increases and reduces the $\mathrm{pH}$ value of saliva creating an acidic environment. The chloride ions attack the oxidation layer of dental implants leading to a corroded implant-abutment connection [17]. Hence, sterile saline can be used to reduce the minimal traces of chloride on implant surface [28]. However, $\mathrm{Cl}$ can be completely removed from the Ti implant surfaces either by rinsing or ultra-sonication, both in ultra-pure water [29].

\subsection{Sulphur (S)}

Sulphur (S) compounds as well as $\mathrm{Na}, \mathrm{K}, \mathrm{Ca}, \mathrm{PO}_{4}, \mathrm{CO}_{2}$ and mucin can be found in the mouth [30]. Traces of sulphates along with fluorides, magnesium oxides, silicates, and calcium oxides are found as a result of the sandblasting and etching process of the implant surfaces [31]. Hydrochloric acid $(\mathrm{HCl})$ and sulphuric acids $\left(\mathrm{H}_{2} \mathrm{SO}_{4}\right)$ are frequently used to pre-treated Ti surfaces. $\mathrm{S}$ from the residual $\mathrm{S}_{2} \mathrm{O}_{8}{ }^{2-}$ or $\mathrm{SO}_{4}{ }^{2-}$ was detected from the samples treated with either Sodium persulfate $\left(\mathrm{Na}_{2} \mathrm{~S}_{2} \mathrm{O}_{8}\right)$ or $\mathrm{H}_{2} \mathrm{SO}_{4}$. However, the Tiacid complexes (titanium sulfate) was less dissolved in water, thus not suitable for decontamination of Ti surfaces as it can disturb the chemical modification of Ti surface [26]. Giner et al. demonstrated that a double acid etching treatment using hydrofluoric acid followed by sulfuric acid produced a dual roughness Ti surface which improved osteoblast adhesion, proliferation and differentiation thus enhancing osseointegration. $S$ can be completely removed from the Ti samples by the non-thermal plasma treatment but not by UV treatment [32].

\subsection{Sodium $(\mathrm{Na})$}

Traces of $\mathrm{Na}$ have also been reported on implant surfaces which have been treated with sodium-containing solutions such as saline and sodium hypochlorite, with sodium hypochlorite causing a tenfold higher amount of trace $\mathrm{Na}$ than saline [28]. $\mathrm{NaOH}$ has been used in alkaline treatment to create a sodium titanate layer by incorporating $\mathrm{Na}$ ions onto the Ti surface. The nanoporous hydroxyapatite/ sodium titanate bilayer has been reported to improve invivo osteoconduction and osteointegration [33]. Moreover, the treatment of hydrophilicity of Ti discs using $\mathrm{NaOH}$ tend to enhance the early stages of cell adhesion, proliferation, and differentiation [34]. In one study, SBF solution has been used during a coating procedure for Ti implants, causing precipitation of many minerals (e.g. $\mathrm{Na}, \mathrm{Ca}, \mathrm{Mg}$, P) presented in the solution, which leads to a higher wear resistance of the implant surface [35]. A study done by Shibli et al. revealed traces of $\mathrm{Na}$ contaminant along with carbon, $\mathrm{O}, \mathrm{N}, \mathrm{Ca}, \mathrm{Al}$, and $\mathrm{O}$ on the Ti surface of the failed implants. The influence of the contaminants block the sites for the oxygen cathodic reaction thus preventing foreign ions such as iron or chromium to catalyse the oxygen 
reaction. Hence, causing an increase in the dissolution rate of Ti implants and preventing re-osseointegration [36].

\subsection{Aluminium (Al)}

Surface analysis of Ti implants using X-ray Photoelectron Spectroscopy (XPS) measurements revealed the presence of $\mathrm{Al}$ and fluoride which were deposited during the sandblasting and acid etching process [37]. The oxidized state of $\mathrm{Al}$, (alumina) is considered to be stable in physiological fluids with very minor tissue reaction. Therefore, it has been used as a coating material to enhance the corrosion resistance characteristics of dental implants [15]. In addition, favourable cell reactions were observed for a rough Ti surface enriched with $\mathrm{Al}, \mathrm{Ca}$ and $\mathrm{P}$ ions, when incorporated into the Ti surface appears to improve viability of osteoblasts [22].

Some Ti dental implants may contain surface contaminants that may cause a problem during the osseointegration process. A study done by Semez et al. [38] showed that the amount of $\mathrm{Al}$ in a dental implant called MYIMPLANT (Nobel Biocare, India) was 12-fold higher than that found in Ti alloys typically used for dental implants (between 0 and about 0.06) [38]. Furthermore, another study suggested that a high concentration of residual aluminium oxide $\left(\mathrm{AlO}_{2}\right)$ may interfere negatively with the osseointegration process [39].

\subsection{Silicon (Si)}

Si was detected on the failed implants along with $\mathrm{P}, \mathrm{Ca}$, $\mathrm{Na}, \mathrm{S}, \mathrm{Cl}, \mathrm{Zn}$ and copper ( $\mathrm{Cu}$ ) on the Ti surface. It has been suggested that the surface contaminants may enhance the inflammatory response, altering the healing process which leads to alteration of the oxide layer surface and failure in reosseointegration. The presence of $\mathrm{Si}$ is possibly due to the passivation process where the $\mathrm{Si}$ was used as a coating or in treating Ti surfaces $[36,40]$. Other than the passivation process, Si may come from ion dissolution from the glass storage vials or probably (less likely) from rubber gloves. It may also originate from the fabrication process, cleaning and sterilization process, the handling environment and storage (glass vials) and analysis preparation procedures [36].

Nevertheless, Si plays an essential element in bone metabolism including promoting osteoblast differentiation, stimulation of collagen type I synthesis, allowing human cell adherence and mineralization of human tissue $[41,42]$. As such, $\mathrm{Si}$ has been used as a coating on $\mathrm{Ti}$ dental implants forming a Si sol-gel coating Ti. A study done by Martınez-lbanez et al. [43] showed that the incorporation of tetraethyl orthosilicate (TEOS) to the sol-gel Si caused hydrolytic degradation that leads to releasing of $\mathrm{Si}$ compound to the media. This resulted in an increase in the effect of osteoinductive properties allowing for direct contact between new bone and the Ti implant [43]. Silicon-based coatings have properties in preventing bacterial infection post-implantation and therefore improved patient outcomes [44].

\subsection{Zinc (Zn)}

Dental implants made of $\mathrm{Zn}$ were reported to cause dental metal allergy in Japan [45]. Some of the traces of $Z n$ ion can be found as this metal is added to toothpaste and mouthwash solutions as anti-plaque agents. This activity is believed to be due to retention in 'oral micro reservoirs' such as soft oral tissues, tooth surfaces and bacterial plaque [40]. Nevertheless, $\mathrm{Zn}$ has been recognized as an important trace element in increasing the cell proliferation in osteoblasts, bone formation and biomineralization. In addition, $\mathrm{Zn}$ has antibacterial properties therefore, attracting researchers to incorporate the $\mathrm{Zn}$ into Ti surfaces in dental implants to enhance bioactivity. Co-implanted $\mathrm{Zn}$ and $\mathrm{Mg}$ ions into Ti implants showed good osteoinductivity, pro-angiogenic and bacterial effects which can enhance rapid osseointegration $[1,46]$.

\subsection{Fluorine (F)}

Traces of $\mathrm{F}$ and $\mathrm{S}$ can be found during the acid-etching process [40]. Fluoride ions (up to $0.1 \mathrm{wt} \%$ ) can also be found in commercial toothpaste, mouthwash solutions and prophylactic gels. Its functions are to prevent development of dental caries and to alleviate dental sensitivity. However, high concentrations of fluoride ions exhibit negative effects on the protective oxide layer of $\mathrm{Ti}$ and its alloys, triggering localized corrosive degradation. The degree of corrosion of Ti and its alloys are depends on the concentration of fluoride ions and the $\mathrm{pH}$ of the fluoride-containing environments [14, 17, 47]. Besides, at a concentrations of $3 \mathrm{ppm}$ of fluoride ions, Ti alloy becomes discoloured and at a concentration above $20 \mathrm{ppm}$, the protective oxide layer becomes degraded [47]. Discoloration of Ti implants can be observed after undergoing autoclaving due to $\mathrm{F}$ contamination [48].

\subsection{Hydrogen $(\mathrm{H})$}

An acid etching technique is popularly used by manufacturers to texture the surface of dental implants. Combination of acids such as hydrofluoric acid-nitric acid are often used to remove the oxide layer of Ti surfaces. In the hydrofluoric acid pretreatment of Ti surfaces, the former attacks the oxide layer and reacts with Ti to form soluble Ti fluorides and $\mathrm{H}$. When the free $\mathrm{H}$ is saturated, titanium 
hydride is formed. The titanium hydride can dramatically affect the mechanical properties of Ti which cause embrittlement of the surface layer. However, by adding nitric acid, it can reduce free $\mathrm{H}$ formation $[13,49]$.

A study on the fracture surface of retrieved Ti screw threads revealed a high amount of $\mathrm{H}$ absorption from biological environment of oral cavity to cause delayed fracture of a Ti implant [50]. A synergistic role of Si and $\mathrm{H}$ coating improves their interaction with osteoblasts. A study done by Mussano et al. [51] revealed that hydrogenrich films increased keratinocytes adhesion and viability thus enhancing osseointegration.

\section{Organic contaminants}

\subsection{Hydrocarbons}

The contamination of $\mathrm{Ti}$ implant surfaces takes only 4 weeks for the freshly cut or previously photo-functionalized implants to be covered with hydrocarbons no matter the type of surface treatment they have undergone [37]. The presence of hydrocarbon on the Ti surface may lessen osteoblast attachment as the cell adhesion protein cannot attach to such sites [52]. Moreover, hydrocarbon found in the air, water, or cleaning fluid can be continuously adsorbed onto the Ti surface and significantly reduce the hydrophilicity of Ti during storage [53]. Photo-functionalization has proven to be a valid method to reduce the amount of hydrocarbon contamination on Ti dental implants and improve osseointegration [37].

\subsection{Carboxylates}

Carboxylates can be found from the coating of Ti surfaces. Carboxylated multi-walled carbon nanotube coated Ti has been shown to have increased osteoblast proliferation, differentiation, and matrix mineralization [54]. However, carboxylates contaminants can cause adverse effects on Ti surface. High amounts of carboxyl groups from carboxylates and hydrocarbon can increase the (super) hydrophilicity of Ti. This subsequently decrease the bonding with the oxide, $\mathrm{N}$, and $\mathrm{S}$ atoms on protein and reduce the attachment of cells. In order to remove the carboxylate contaminant, high-energy photons such as non-thermal plasma and UV light are required to break the weak bonds between carboxyl groups and Ti [31].

\subsection{Salts of organic acids}

The production of organic acids come from the process of glycolysis by bacteria and may reduce $\mathrm{pH}$ to create a favourable environment for aerobic bacteria.
Accumulation of organic acids leads to an acidic environment and induces corrosion and discolouration of $\mathrm{Ti}$ implants [55].

\subsection{Nitrogen from ammonium residues}

Presence of substances, like $\mathrm{N}, \mathrm{C}, \mathrm{O}, \mathrm{Ca}$, and $\mathrm{P}$, found on the surface of the Ti healing abutments form a white residue. These white residues cause obstruction on the Ti surface. The existence of $\mathrm{N}$ and other elements residue may come from bacterial plaque, bolus, soft-tissue or protein compounds in saliva that have adhered to the Ti surface [2]. In addition, bacterial biofilm increased the percentage of both carbon and nitrogen on the Ti surface. By using $\mathrm{H}_{2} \mathrm{O}_{2}$ photolysis, the degraded biocompatibility of biofilm-contaminated Ti surfaces can be recovered and may have the potential for improving peri-implantitis [52].

A study reported that the microwave-assisted drying of HA (hydroxyapatite) samples were found to be effective in inhibiting the growth of Escherichia coli. The formation of ammonium nitrate during the drying process when calcium nitrate and ammonia were added into the solution for $\mathrm{TiO}_{2}$ synthesis. The resultant, ammonium nitrate, acts as an oxidant for the combustion reaction [56].

\subsection{Bacteria}

Bacterial colonization can damage the surface $\mathrm{TiO}_{2}$ layer. A study reported that the colonization of bacteria demonstrates more prominent damage on the surface morphology and chemistry of implant surfaces [57]. Bacteria can cause microbial corrosion where the acidic waste products created by microbes generate an acidic environment. The corrosion may lead to inflammation and occurrence of peri-implantitis. The severity of microbial corrosion can be reduced by using antibiotic sprays and dips to minimize microbe populations $[14,17]$. Bacterial contamination can occur on dental implants during surgery and affect the osseointegration and the prognosis in a clinically significant way; however scientific evidence in a systematic review concerning this is insufficient [58].

Combined usage of antiseptics such as chlorhexidine digluconate $(\mathrm{CHX})$ or hydrogen peroxide $\mathrm{H}_{2} \mathrm{O}_{2}$ and photodynamic therapy (PDT) was more effective in eliminating bacteria biofilm. This was supported by a study where the combination of antiseptics and PDT showed effective decontamination ability in eradicating Staphylococcus aureus biofilm from Ti surfaces [59].

Despite a wide range of organic and inorganic impurities that may contaminate dental implant surfaces, the 10 year clinical survival rate of the most commonly used oral implants is in the range of $90-95 \%$ and the results of 
"modern, moderately rough oral implants are between 95 and $99 \%$ at 10 years.[60].

\section{Conclusion}

This review is targeted at both manufacturers and clinicians. Contaminations of dental implants are intimately associated with implant failures. From the summarization of the review (see Table 1), the contaminants may become beneficial and/or produce disastrous effects on dental implants. These may alter the surface energy, chemical purity, thickness and composition of the oxide layer. It is also known that the most common elemental contamination of $\mathrm{Ti}$ surfaces, potentially linked to implant failures are trace elements such as $\mathrm{N}, \mathrm{Ca}, \mathrm{P}, \mathrm{Cl}, \mathrm{S}, \mathrm{Na}$, Si and $\mathrm{F}$, some organic carbons and bacterial cells / by-products. However, some of the contaminants such as Si and $\mathrm{P}$ are beneficial to the dental implants that promote osseointegration. The traces of organic and inorganic contaminants can be found from the implant cleaning process, Ti surface treatment such as acid-etching and sand-blasting, biological environment and also the surrounding environment. Various methods of removing contaminants are also introduced with the hope of promoting osseointegration.

Acknowledgements This study is supported by the University Research Council under Universiti Brunei Darussalam with the Grant Number UBD/RSCH/URC/RG(b)/2018/004, led by Dr Jagjit Singh Dhaliwal (Principal Investigator).

\section{Compliance with ethical standards}

Conflict of interest The authors declare that they have no conflict of interest.

Open Access This article is licensed under a Creative Commons Attribution 4.0 International License, which permits use, sharing, adaptation, distribution and reproduction in any medium or format, as long as you give appropriate credit to the original author(s) and the source, provide a link to the Creative Commons licence, and indicate if changes were made. The images or other third party material in this article are included in the article's Creative Commons licence, unless indicated otherwise in a credit line to the material. If material is not included in the article's Creative Commons licence and your intended use is not permitted by statutory regulation or exceeds the permitted use, you will need to obtain permission directly from the copyright holder. To view a copy of this licence, visit http://creativecommons .org/licenses/by/4.0/.

\section{References}

1. Yu Y, Jin G, Xue Y, Wang D, Liu X, Sun J (2017) Multifunctions of dual $\mathrm{Zn} / \mathrm{Mg}$ ion co-implanted titanium on osteogenesis, angiogenesis and bacteria inhibition for dental implants. Acta Biomater 49:590-603. https://doi.org/10.1016/j.actbio.2016.11.067
2. Wheelis SE, Valderrama TGW, Rodrigues DC (2017) Surface characterization of titanium implant healing abutments before and after placement. Clin Implant Dent Relat Res. https://doi. org/10.1111/cid. 12566

3. Schlee M, Rathe F, Brodbeck U, Ratka C, Weigl P, Zipprich H (2019) Treatment of peri-implantitis-electrolytic cleaning versus mechanical and electrolytic cleaning: a randomized controlled clinical trial-six-month results. J Clin Med 8:1909

4. Elias CN (2011) Implant dentistry. In: Turkyilmaz I (ed) A rapidly evolving practice. IntechOpen, Vienna

5. Sukumaran A, Anand PS, Alghamdi H, Jansen JA (2011) Dental implant surface enhancement and osseointegration. Inplant Dent. https://doi.org/10.13140/2.1.2991.2644

6. Singh J, Nurul D, Rahman A, Knights J, Ghani H (2019) The effect of different surface topographies of titanium implants on bacterial biofilm: a systematic review. SN Appl Sci. https://doi. org/10.1007/s42452-019-0638-6

7. Wennerberg A, Albrektsson T (2010) On implant surfaces: a review of current knowledge and opinions. Int J Oral Maxillofac Implants 74:63-74

8. Rezaei NM, Hasegawa M, Ishijima M, Nakhaei K, Okubo T, Taniyama T, Ogawa T (2018) Biological and osseointegration capabilities of hierarchically (Meso-/micro-/nano-scale) roughened zirconia. Int J Nanomed 13:3381-3395. https://doi.org/10.2147/ IJN.S159955

9. Al-Hashedi AA, Laurenti M, Benhamou V, Tamimi F (2017) Decontamination of titanium implants using physical methods. Clin Oral Implant Res 28(8):1013-1021. https://doi.org/10.1111/ clr.12914

10. Mombelli A, Hashim D, Cionca N (2018) What is the impact of titanium particles and biocorrosion on implant survival and complications? A critical review. Clin Oral Implant Res 29:37-53. https://doi.org/10.1111/clr.13305

11. Katona B, Dobos G, Kiss G (2015) Examination of the surface phosphorus content of anodized medical grade titanium samples. Mater Sci Forum 812:339-344. https://doi.org/10.4028/ www.scientific.net/msf.812.339

12. Šupová $M$ (2015) Substituted hydroxyapatites for biomedical applications: a review. Ceram Int 41(8):9203-9231. https://doi. org/10.1016/j.ceramint.2015.03.316

13. Sasikumar Y, Indira K, Rajendran N (2019) Surface modification methods for titanium and its alloys and their corrosion behavior in biological environment: a review. J. Bio-Tribo-Corros. https:// doi.org/10.1007/s40735-019-0229-5

14. Chaturvedi (2009) An overview of the corrosion aspect of dental implants (titanium and its alloys). Indian J Dent Res 20(1):9198. https://doi.org/10.4103/0970-9290.49068

15. Bahraminasab M, Bozorg M, Ghaffari S, Kavakebian F (2019) Electrochemical corrosion of $\mathrm{Ti}^{-} \mathrm{Al}_{2} \mathrm{O}_{3}$ biocomposites in Ringer's solution. J Alloys Compd 777:34-43. https://doi.org/10.1016/j. jallcom.2018.09.313

16. Duddeck DU, Albrektsson T, Wennerberg A, Larsson C, Beuer F (2019) On the cleanliness of different oral implant systems: a pilot study. J Clin Med 8:1280

17. Noumbissi S, Scarano A, Gupta S (2019) A literature review study on atomic ions dissolution of titanium and its alloys in implant dentistry. Materials (Basel) 12(3):1-15. https://doi.org/10.3390/ ma12030368

18. Shadid RM, Sadaqah NR, Othman SA (2014) Does the implant surgical technique affect the primary and/or secondary stability of dental implants ? A systematic review. Int J Dent 2014:17. https://doi.org/10.1155/2014/204838

19. Jha N, Ryu JJ, Choi EH, Kaushik NK (2017) Review article generation and role of reactive oxygen and nitrogen species induced by plasma, lasers, chemical agents, and other 
systems in dentistry. Oxid Med Cell Longev 2017:13. https:// doi.org/10.1155/2017/7542540

20. Berbel LO, BanczekKarousis EP, Kotsakis IK, Costa GA (2019) Determinants of corrosion resistance of Ti-6Al-4V alloy dental implants in an In Vitro model of peri-implant inflammation. PLoS ONE 14(1):1-17. https://doi.org/10.1371/journal.pone.0210530

21. Kizuki T, Takadama H, Matsushita T, Nakamura T, Kokubo T (2013) Effect of Ca contamination on apatite formation in a Ti metal subjected to $\mathrm{NaOH}$ and heat treatments. J Mater Sci 24(3):635644. https://doi.org/10.1007/s10856-012-4837-6

22. Lukaszewska-Kuska M, Wirstlein P, Majchrowski R, DorockaBobkowska B (2018) Osteoblastic cell behaviour on modified titanium surfaces. Micron 105:55-63. https://doi.org/10.1016/j. micron.2017.11.010

23. França FL, Honorio-França AC, Honoria MS, da Silva FH, Fujimori M, França EL, da Araújo FG, S. (2019) Dental implant surfaces treated with phosphoric acid can modulate cytokine production by blood MN cells. Braz Oral Res 33(e040):1-10. https://doi. org/10.1590/1807-3107bor-2019.vol33.0040

24. Trisi P, Berardini M, Falco A, Sandrini E, Vulpiani MP (2017) A new highly hydrophilic electrochemical implant titanium surface: a histological and biomechanical in vivo study. Implant Dent 26(3):429-437. https://doi.org/10.1097/ID.0000000000000605

25. Wheelis SE, Wilson TG, Valderrama P, Rodrigues DC (2018) Surface characterization of titanium implant healing abutments before and after placement. Clin Implant Dent Relat Res 20(2):180-190. https://doi.org/10.1111/cid.12566

26. Takeuchi $M$, Abe $Y$, Yoshida $Y$, Nakayama $Y$, Okazaki M, Akagawa $Y$ (2003) Acid pretreatment of titanium implants. Biomaterials 24(10):1821-1827. https://doi.org/10.1016/S0142 $-9612(02) 00576-8$

27. Sedlaczek J, Lohmann CH, Lotz EM, Hyzy SL, Boyan BD, Schwartz Z (2017) Effects of low-frequency ultrasound treatment of titanium surface roughness on osteoblast phenotype and maturation. Clin Oral Implant Res 28(10):e151-e158. https://doi. org/10.1111/clr.12976

28. Kotsakis GA, Lan C, Barbosa J, Lill K, Chen R, Rudney J, Aparicio $C$ (2016) Antimicrobial agents used in the treatment of periimplantitis alter the physicochemistry and cytocompatibility of titanium surfaces. J Periodontol 87(7):809-819. https://doi. org/10.1902/jop.2016.150684

29. Zinelis S, Silikas N, Thomas A, Syres K, Eliades G (2012) Surface characterization of SLActive dental implants. Eur J Esthet Dent 7(1):72-92

30. Oshida Y, Tuna EB, Aktören O, Gençay K (2010) Dental implant systems. Int J Mol Sci 11(4):1580-1678. https://doi.org/10.3390/ ijms11041580

31. Henningsen A, Smeets R, Heuberger R, Jung OT, Hanken H, Heiland $M$, Precht $C$ (2018) Changes in surface characteristics of titanium and zirconia after surface treatment with ultraviolet light or non-thermal plasma. Eur J Oral Sci 126(2):126-134. https ://doi.org/10.1111/eos.12400

32. Giner $L$, Mercadé $M$, Torrent $S$, Punset $M$, Pérez RA, Delgado LM, Gil FJ (2018) Double acid etching treatment of dental implants for enhanced biological properties. J Appl Biomater Funct Mater 16(2):83-89. https://doi.org/10.5301/jabfm.5000376

33. Carrado A, Perrin-Schmitt F, Le QV, Giraudel M, Fischer C, Koenig G, Pourroy G (2016) Nanoporous hydroxyapatite/sodium titanate bilayer on titanium implants for improved osteointegration. Dent Mater 33(3):331-332. https://doi.org/10.1016/j.denta I.2016.12.013

34. Jiang J, Han G, Zheng X, Chen G, Zhu P (2019) Characterization and biocompatibility study of hydroxyapatite coating on the surface of titanium alloy. Surf Coat Technol 375:645-651. https ://doi.org/10.1016/j.surfcoat.2019.07.067
35. Kumar DD, Kaliaraj GS (2018) Multifunctional zirconium nitride/ copper multilayer coatings on medical grade $316 \mathrm{~L}$ SS and titanium substrates for biomedical applications. J Mech Behav Biomed Mater 77:106-115. https://doi.org/10.1016/j.jmbbm 2017.09.007

36. Shibli JA, Marcantonio E, D'Avila S, Guastaldi AC, Marcantonio EM Jr (2005) Analysis of failed commercially pure titanium dental implants : a scanning electron microscopy and energy-dispersive spectrometer X-ray study. J Periodonto 76(7):1092-1099

37. Roy M, Pompella A, Kubacki J, Szade J, Roy RA, Hedzelek W (2016) Photofunctionalization of titanium: an alternative explanation of its chemical-physical mechanism. PLoS ONE 11(6):111. https://doi.org/10.1371/journal.pone.0157481

38. Semez G, Todea C, Mocuta D, Sas IT, Luca R (2018) Chemical and morphologic analysis of titanium dental implants: X-ray photoemission techniques (XPS) and scanning electron microscopy (SEM) with EDX analysis. Rev Chim 69(2):474-477

39. Canabarro A, Diniz MG, Paciornik S, Carvalho L, Sampaio EM, Beloti MM, Fischer RG (2008) High concentration of residual aluminum oxide on titanium surface inhibits extracellular matrix mineralization. J Biomed Mater Res 87A(3):588-597. https://doi.org/10.1002/jbm.a.31810

40. Lázaro P, Herrero M, Gil FJ (2010) Evaluation of titanium dental implants after early failure of osseointegration by means of $\mathrm{X}$-ray photoelectron spectoscopy, electron microscopy and histological studies. J Biomed Sci Eng 03(11):1073-1077. https ://doi.org/10.4236/jbise.2010.311139

41. Bartkowiak A, Suchanek K, Menaszek E, Szaraniec B, Lekki J, Perzanowski M, Marszałek M (2018) Biological effect of hydrothermally synthesized silica nanoparticles within crystalline hydroxyapatite coatings for titanium implants. Mater Sci Eng 92:88-95. https://doi.org/10.1016/j.msec.2018.06.043

42. Romero-gavilan F, Araújo-gomes N, Sánchez-pérez AM, Garcíaarnáez I (2018) Bioactive potential of silica coatings and its effect on the adhesion of proteins to titanium implants. Colloids Surf B 162:316-325. https://doi.org/10.1016/j.colsu rfb.2017.11.072

43. Martınez-lbanez M, Juan-Diaz MJ, Lara-Saez I, Coso A, Franco J, Gurruchaga M, Goni I (2016) Biological characterization of a new silicon based coating developed for dental implants. J Mater Sci. https://doi.org/10.1007/s10856-016-5690-9

44. Gifford SM, Hu H, Kinser ER, Yu RR, Zafar S (2018) Antibacterial medical implant surface. United States Patent Application Publication. Patent no. 5217493, June 8, 1993

45. Kitagawa M, Murakami S, Akashi Y, Oka H, Shintani T, Ogawa I, Kurihara H (2019) Current status of dental metal allergy in Japan. J Prosthodont Res 2018:1-4. https://doi.org/10.1016/j. jpor.2019.01.003

46. Deng C, Shen X, Yang W, Luo Z, Ma P, Shen T, Cai K (2018) Construction of zinc-incorporated nano-network structures on a biomedical titanium surface to enhance bioactivity. Appl Surf Sci 453:263-270. https://doi.org/10.1016/j.apsusc.2018.05.097

47. Xu J, Ma JJ, Munroe P, Xie ZH (2018) Influence of Fluoride ion concentrations on the corrosion behavior of Ta2N nanocrystalline coating for dental implant applications. Surf Rev Lett 25(4):1-19. https://doi.org/10.1142/S0218625X1850083X

48. Lausmaa J, Kasemo B, Hansson S (1985) Accelerated oxide growth on titanium implants during autoclaving caused by fluorine contamination. Biomaterials 6(1):23-27. https://doi. org/10.1016/0142-9612(85)90033-X

49. Szmukler-Moncler S, Bischof M, Nedir R, Ermrich M (2010) Titanium hydride and hydrogen concentration in acid-etched commercially pure titanium and titanium alloy implants: a comparative analysis of five implant systems. Clin Oral Implant Res 21:944-950. https://doi.org/10.1111/j.1600-0501.2010.01938.x 
50. Yokoyama K, Ichikawa T, Murakami H, Miyamoto Y, Asaoka K (2002) Fracture mechanisms of retrieved titanium screw thread in dental implant. Biomaterials 23:2459-2465

51. Mussano F, Genova T, Laurenti M, Munaron L, Pirri CF, Rivolo P, Mandracci P (2018) Hydrogenated amorphous silicon coatings may modulate gingival cell response. Appl Surf Sci 436:603-612. https://doi.org/10.1016/j.apsusc.2017.11.283

52. Nakamura $K$, Shirato M, Tenkumo $T$, Kanno T, Westerlund $A$, Örtengren U, Niwano Y (2019) Hydroxyl radicals generated by hydrogen peroxide photolysis recondition biofilm-contaminated titanium surfaces for subsequent osteoblastic cell proliferation. Sci Rep 9(1):1-19. https://doi.org/10.1038/s41598-01941126-z

53. Jiang L, Jin S, Geng S, Deng C, Lin Z, Zhao B (2019) Maintenance and restoration effect of the surface hydrophilicity of pure titanium by sodium hydroxide treatment and its effect on the bioactivity of osteoblasts. Coatings 9(222):1-19. https://doi. org/10.3390/coatings 9040222

54. Subramani K, Pandruvada SN, Puleo DA, Hartsfield JK, Huja SS (2016) In vitro evaluation of osteoblast responses to carbon nanotube-coated titanium surfaces. Prog Orthodont 17(1):23. https://doi.org/10.1186/s40510-016-0136-y

55. Siddiqui DA, Guida L, Sridhar S, Valderrama P, Wilson TG, Rodrigues DC (2019) Evaluation of oral microbial corrosion on the surface degradation of dental implant materials. J Periodontol 90(1):72-81. https://doi.org/10.1002/JPER.18-0110

56. Lamkhao S, Phaya M, Jansakun C, Chandet N, Thongkorn K, Rujijanagul G, Randorn C (2019) Synthesis of hydroxyapatite with antibacterial properties using a microwave-assisted combustion method. Sci Rep 9(1):1-9. https://doi.org/10.1038/s41598-01940488-8

57. Sridhar S, Wang F, Wilson TG, Valderrama P, Palmer K, Rodrigues DC (2018) Multifaceted roles of environmental factors toward dental implant performance: observations from clinical retrievals and in vitro testing. Dent Mater 34(11):e265-e279. https:// doi.org/10.1016/j.dental.2018.08.299

58. Johansson K, Jimbo R, Östlund P, Tranæus S, Becktor JP (2017) Effects of bacterial contamination on dental implants during surgery: a systematic review. Implant Dent 26(5):778-789. https ://doi.org/10.1097/ID.0000000000000660

59. Cai Z, Li Y, Wang Y, Chen S, Jiang S, Ge H, Huang X (2019) Antimicrobial effects of photodynamic therapy with antiseptics on Staphylococcus aureus biofilm on titanium surface. Photodiagn Photodyn Ther 25(January):382-388. https://doi.org/10.1016/j. pdpdt.2019.01.024

60. Wennerberg A, Albrektsson T, Chrcanovic B (2018) Long-term clinical outcome of implants with different surface modifications. Eur J Oral Implant 11:123-136

Publisher's Note Springer Nature remains neutral with regard to jurisdictional claims in published maps and institutional affiliations. 